\title{
Feed intake by grazing dairy cows. 3 . Comparison of lactating and dry pregnant cows
}

\author{
N. D. Dijkstra
}

Institute for Livestock Feeding and Nutrition Research, Hoorn, the Netherlands

Received: 26 August 1971

\section{Summary}

In earlier experiments a method of estimation of the grass intake was developed by using polyethylene as exogeneous faecal marker and indigestible crude protein as endogeneous marker. In these trials fistulated cows were used to be sure of an absolutely quantitative ingestion of the exogeneous marker by inserting the marker in the rumen fistulae.

In this third experiment normal cows were used. Now the capsules with polyethylene were administered orally with good results.

In this experiment the grass intake of lactating cows is compared with that of dry pregnant cows, about 1-2 months before calving. The average dry matter intakes were 15.2 and $11.7 \mathrm{~kg}$, respectively, on an average per cow per day, with a significant difference of $3.57 \pm 0.19 \mathrm{~kg}$.

The average daily intake of nutritive value was estimated for the lactating cows on $9.2 \mathrm{~kg}$ of starch equivalent and $3.5 \mathrm{~kg}$ of digestible crude protein; for the dry cows these figures were 7.1 and $2.7 \mathrm{~kg}$, respectively.

\section{Introduction}

Many research workers of different countries have already done a lot of work to obtain a method which permits calculation of the feed intake of grazing ruminants. However, up to now we did not find a method giving completely satisfactory results.

By moving and weighing the grass of small plots before and after pasturing we can get an impression of the grass used, but this is not identical with the grass intake, because a part of the grass is trampled down by the cows. Consequently, different methods for determining herbage intake by faecal techniques have been developed in the last decades.

In the first paper of this series (Kemmink and Dijkstra, 1968) the reliability of some faecal markers was tested in digestibility trials with wethers, in which the faeces were completely collected. In this trial one of the markers was 'Microthene Polyethylene Powder-M 710' made by U.S. Industrial Chemical Company.

We found that this polyethylene powder was a good marker. Total collection of faeces was not essential for accuracy, if all the weighed polyethylene was ingested. Faeces may be sampled 5 days after the first gift of the marker. With its fine grade and its low specific gravity, its rate of passage will be similar to that of the feed. The powder does not affect the palatability or digestibility of the ration. None of it is ab- 
sorbed or retained in the gut and moreover it was easily to determine by a modification of the method of Chandler et al. (1964).

Our results with chromic oxide paper were not quite satisfactory. There are not only practical difficulties in the manufacture of the shredded paper and in its variation in moisture content, but also there is some absorption or retention in the gut so that less than $95 \%$ was recovered.

\section{Our first experiment in pasture}

In the second paper (Dijkstra and Kemmink, 1970) the use of these exogeneous and three endogeneous markers were tested in two grazing experiments of 4 weeks each.

The first experiment was carried out in September 1967 with 5 dry cows and the second experiment in August 1968 with 5 cows, with an average daily milk yield of about $12 \mathrm{~kg}$. A system of strip-grazing was adopted in which electric fences were moved in front of the cattle. Simultaneously electric fences were set up behind the group, so that the offered pasture area was always of the same magnitude. The fences were moved two times a week; consequently there were 8 periods of 3 and 4 days.

The area of the strips were in 1967 about 1 are $\left(100 \mathrm{~m}^{2}\right)$ per cow per day. In the first period of this trial the grass yield was about $10,000 \mathrm{~kg} / \mathrm{ha}$. During the trial this increased regularly, and consequently in the last (8th) period is was about $26,000 \mathrm{~kg} / \mathrm{ha}$.

In 1968 the offered pasture area was about 1.5 are per cow per day, but - by cutting each strip about one month before grazing - the grass yield was about $15,000 \mathrm{~kg}$ fresh grass per ha all the time.

In both experiments fistulated cows were used in order to administer the faecal markers easily and quantitatively. In 1967 each cow received through the fistula two times a day 2 capsules with $12.5 \mathrm{~g}$ chromic oxide paper and 3 capsules with $7.5 \mathrm{~g}$ polyethylene powder, corresponding with $15.535 \mathrm{~g} \mathrm{Cr}_{2} \mathrm{O}_{3}$ and $45 \mathrm{~g}$ polyethylene per cow per day. In 1968 each cow received two times a day 4 capsules polyethylene, this means $60 \mathrm{~g}$ per cow per day.

Moreover, the herbage consumption was estimated in both years by cutting grass, grown in cages and by a strip-cutting method. The use of $\mathrm{Cr}_{2} \mathrm{O}_{3}$ as marker in 1967 resulted in an about $20 \%$ higher calculated faeces production and, consequently, in a $20 \%$ higher calculated grass intake. In view of this unlikely high figure and the results of preliminary experiments in our first paper, we assumed the method with polyethylene as to be the most accurate one.

Three different methods are used to calculate the grass intake from the faeces production, viz:

a. the chromogen content,

b. the digestibility of the organic matter and

c. the digestible crude protein content.

By using the methods $b$ and $c$ the grass intake in 1968 was about $14 \%$ higher as in 1967. This seems logic (cows in lactation and a larger available area per day). However, by calculating with chromogen content (method a) the intake in both years was about the same.

This result, together with the big variations in the calculated grass intakes from one period to the other, makes us consider method a as to be the least reliable one.

In a critical judgement of these indirect calculations of the grass intake, we have to consider that the grass samples are obtained by cutting. By grazing in a sufficient 
FEED INTAKE BY GRAZING DAIRY COWS. 3

Table 1. Calculated trampling losses.

\begin{tabular}{llll}
\hline Year & $\begin{array}{l}\text { Area/cow per day } \\
\text { (are) }\end{array}$ & $\begin{array}{l}\text { Grass yield } \\
(\mathrm{kg} / \mathrm{ha})\end{array}$ & $\begin{array}{l}\text { Trampling Iosses } \\
(\%)\end{array}$ \\
1967 & 1 & 11,000 & 12 \\
1967 & 1 & 16,000 & 22 \\
1967 & 1 & 26,000 & 41 \\
1968 & 1.5 & 15,000 & 33 \\
\hline
\end{tabular}

amount of grass the cows are able to select their fodder. They eat in the first place the more leafy parts and do not touch a part of the stems. Consequently, it is most probable that the digestibility of the organic matter of the grass eaten by the cows, is higher than we have found by using cut samples. If the digestibility is higher the percentage indigestible organic matter in the grass is lower and consequently the grass intake, calculated by method $b$ is probably too low.

Finally, method $\mathrm{c}$ : the calculation by using the content of apparent indigestible crude protein in the grass. This content was calculated on organic matter base by using the formula $0.058 \mathrm{x}+4.09$, in which $\mathrm{x}=$ crude protein content in organic matter of the grass samples. In this formula the standard deviation of the constant factor is very small, whereas we start for the regression coefficient 0.058 from the assumption that the true digestibility of the protein of this grass is $94.2 \%$. Also for this calculation we use grass samples obtained by cutting.

Supposing that the grass selected by the cows is better, the digestibility of this grass will be higher and the digestibility of the protein will be higher too. Consequently, the factor 0.058 will be lower. On the other side in this selected grass the protein content (x) will be higher. Both factors work in opposite direction and, moreover, the variable factor is small with regard to the constant factor.

Based on these theoretical considerations we concluded that the calculation by use of a formula for the apparent indigestible crude protein content of the grass will give the most accurate approach of the real grass intake.

By this way of calculation the average organic matter intake per cow per day was calculated in each of the periods. This corresponded with an average daily dry matter intake of the dry cows in the experiment in 1967 of $12.80 \mathrm{~kg}$ and with that of the lactating cows in 1968 of $14.58 \mathrm{~kg}$, corresponding with $7.27 \mathrm{~kg}$ and $8.40 \mathrm{~kg}$ starch equivalent, respectively.

Comparing the figures for the grass consumption, obtained by cutting the grass before and after pasturing, and those of the grass intake calculated by the above-mentioned method, we were able to calculate the trampling losses. Table 1 shows the calculated losses (Table 1).

\section{The third experiment in pasture}

The third grazing experiment was carried out in September 1970 with two groups of 6 cows. One group comprised dry, pregnant cows in the last months before calving and the other group lactating cows inorder to compare their grass intakes. Data of these groups are given in Table 2.

The same method of strip-grazing was used as in the earlier experiments with elec- 
Table 2. Data of the cows used in the third experiment.

\begin{tabular}{|c|c|c|c|c|c|}
\hline \multicolumn{2}{|c|}{ Dry pregnant cows } & \multicolumn{4}{|c|}{ Lactating cows } \\
\hline $\begin{array}{l}\text { cow } \\
\text { No }\end{array}$ & future calving date & $\begin{array}{l}\text { cow } \\
\text { No }\end{array}$ & $\begin{array}{l}\text { last calving } \\
\text { date }\end{array}$ & $\begin{array}{l}\text { milk yield } \\
(\mathrm{kg})\end{array}$ & $\begin{array}{l}\text { fat yield } \\
\text { (g) }\end{array}$ \\
\hline 7 & 20 November & 3 & 14 March & 15.4 & 759 \\
\hline 10 & 15 November & 18 & 2 February & 15.0 & 667 \\
\hline 14 & 26 October & 38 & 6 June & 23.2 & 989 \\
\hline 32 & 30 October & 45 & 15 July & 21.7 & 748 \\
\hline 73 & 2 November & 53 & 31 March & 17.0 & 745 \\
\hline 74 & 26 October & 95 & 5 February & 18.7 & 655 \\
\hline Average & 4 November & Average & 8 April & 18.5 & 760 \\
\hline
\end{tabular}

tric fences in front of and behind the cows. Moreover each strip was devided with an electric fence into two equal parts, one group grazing on one side and the other group on the other side of this fence. The area of the strips was for both groups in the first periods about 1 are $\left(100 \mathrm{~m}^{2}\right)$ per cow per day. This experiment lasted 4 weeks and the electric fences were moved two times a week; consequently there were 8 periods of 3 and 4 days. In the first periods it proved that on the last day of these periods the group of lactating cows disposed of a rather scanty amount of grass. Therefore in the following period we preferred to increase the area of the strips for both groups to about $11 / 4$ are per cow per day. By cutting each strip about one month before grazing, the grass yield was all the time about the same $(10,000-15,000 \mathrm{~kg}$ fresh grass per ha).

In the earlier experiments fistulated cows were used to be sure of an absolutely quantitative ingestion of the exogeneous marker. However it is almost impossible to use in this kind of experiments fistulated animals only. Therefore we used in this trial cows without fistulae and tried to administer the capsules with polyethylene orally with a kind of 'pill-shooter'. Each cow received two times a day 4 capsules poly-

Table 3. Chemical composition of the grass.

\begin{tabular}{|c|c|c|c|c|c|c|c|c|c|}
\hline \multirow[t]{3}{*}{ Period } & \multirow{3}{*}{$\begin{array}{l}\text { Data of these } \\
\text { periods }\end{array}$} & \multicolumn{4}{|c|}{ Dry pregnant cows } & \multicolumn{4}{|c|}{ Lactating cows } \\
\hline & & \multirow{2}{*}{$\begin{array}{l}\text { dry } \\
\text { matter } \\
(\%)\end{array}$} & \multicolumn{3}{|c|}{ in dry matter $(\%)$} & \multirow{2}{*}{$\begin{array}{l}\text { dry } \\
\text { matter } \\
(\%)\end{array}$} & \multicolumn{3}{|c|}{ in dry matter $(\%)$} \\
\hline & & & $\begin{array}{l}\text { crude } \\
\text { protein }\end{array}$ & $\begin{array}{l}\text { crude } \\
\text { fibre }\end{array}$ & ash & & $\begin{array}{l}\text { crude } \\
\text { protein }\end{array}$ & $\begin{array}{l}\text { crude } \\
\text { fibre }\end{array}$ & ash \\
\hline 2 & 3- 7 September & 13.77 & 29.20 & 21.57 & 12.46 & 13.50 & 29.13 & 21.63 & 12.29 \\
\hline 3 & 7-10 September & 14.27 & 28.34 & 20.14 & 12.25 & 13.88 & 27.75 & 21.24 & 12.56 \\
\hline 4 & 10-14 September & 13.26 & 28.23 & 21.93 & 12.90 & 13.57 & 26.95 & 20.83 & 12.39 \\
\hline 5 & 14-17 September & 16.11 & 28.16 & 20.77 & 11.90 & 15.98 & 26.37 & 21.06 & 11.72 \\
\hline 6 & 17-21 September & 13.02 & 27.59 & 22.11 & 11.31 & 12.31 & 29.20 & 20.54 & 11.91 \\
\hline 7 & 21-24 September & 12.92 & 31.53 & 20.27 & 11.65 & 13.15 & 29.33 & 20.54 & 11.42 \\
\hline 8 & 24-28 September & 12.41 & 27.82 & 20.38 & 11.40 & 12.29 & 28.82 & 20.51 & 11.15 \\
\hline Average & & 13.68 & 28.70 & 21.02 & 11.98 & 13.53 & 28.22 & 20.91 & 11.92 \\
\hline
\end{tabular}


ethylene, providing in total $60 \mathrm{~g}$ per cow per day. Already in a few days administration of the exogeneous faecal marker had become a routine for men and cows. We intended to eliminate the first two periods, but it proved afterwards that the calculated grass intake in the second period was almost equal to that in the following ones. Consequently, only the first period was eliminated, so that the data of the remaining 7 periods could be used for our calculations.

As in our earlier experiments we collected in this trial two times a day all droppings of the cows which could easily be scraped from the pasture and drew from this a daily sample for analizing. This was done for each group separately.

The same was done with the grass samples, which were cut at several places of the next pasture strips just before the cows were coming in. The composition of the grass did not change much during the experiment as is demonstrated in Table 3.

As was to be expected there was practically no difference between the grass of the pasture strips on both sides of the electric fence.

\section{Calculation of the grass intake}

By use of the content of polyethylene in organic matter of the daily faeces samples, the amount of organic matter excreted in the faeces of both groups of cows could be calculated as an average per cow.

By multiplying these amounts with the crude protein content in organic matter of the daily faeces samples of the concerning group, the average amount of indigestible protein could be calculated.

From the protein content of the grass in the concerning period the content of indigestible protein in organic matter $(y)$ of the grass could be calculated with the formula : $\mathrm{y}=0.058 \mathrm{x}+4.09$, in which $\mathrm{x}=$ protein content in organic matter. By dividing we were able to calculate the intake of organic matter in the concerning period as an average per cow per day. The data calculated in this way are given in Table 4.

The average daily intake of organic matter in grass was for the lactating cows $13.44 \mathrm{~kg}$ and for the dry cows, about 1 to 2 months before calving, $10.28 \mathrm{~kg}$. Converted into dry matter the average daily intakes were 15.25 and $11.68 \mathrm{~kg}$, respectively. The difference between both groups was very significant, viz $3.57 \pm 0.190 \mathrm{~kg}$.

Tabie 4. The grass intake of lactating and dry pregnant cows on an average per cow per day.

\begin{tabular}{|c|c|c|c|c|c|}
\hline \multirow[t]{2}{*}{ Period } & \multicolumn{2}{|c|}{ Organic matter $(\mathrm{kg})$} & \multicolumn{3}{|l|}{ Dry matter (kg) } \\
\hline & lactating cows & dry cows & lactating cows & dry cows & difference \\
\hline 2 & 13.40 & 10.64 & 15.28 & 12.15 & 3.13 \\
\hline 3 & 13.53 & 10.33 & 15.47 & 11.77 & 3.70 \\
\hline 4 & 13.04 & 10.24 & 14.88 & 11.76 & 3.12 \\
\hline 5 & 12.93 & 10.13 & 14.65 & 11.50 & 3.15 \\
\hline 6 & 14.41 & 11.48 & 16.36 & 12.94 & 3.42 \\
\hline 7 & 13.65 & 9.88 & 15.41 & 11.18 & 4.23 \\
\hline 8 & 13.04 & 9.24 & 14.68 & 10.43 & 4.25 \\
\hline Average & $13.44 \pm 0.271$ & $10.28 \pm 0.202$ & $15.25 \pm 0.225$ & $11.68 \pm 0.296$ & $3.57 \pm 0.190$ \\
\hline
\end{tabular}


Table 5. Intake of nutritive value of the grazing cows $(\mathrm{kg})$.

\begin{tabular}{|c|c|c|c|c|}
\hline \multirow[t]{2}{*}{ Period } & \multicolumn{2}{|c|}{ Lactating cows } & \multicolumn{2}{|c|}{ Dry pregnant cows } \\
\hline & $\begin{array}{l}\text { starch equi. } \\
\text { valent }\end{array}$ & $\begin{array}{l}\text { digestible crude } \\
\text { protein }\end{array}$ & $\begin{array}{l}\text { starch equi- } \\
\text { valent }\end{array}$ & $\begin{array}{l}\text { digestible crude } \\
\text { protein }\end{array}$ \\
\hline 2 & 8.90 & 3.64 & 7.26 & 2.91 \\
\hline 3 & 9.25 & 3.49 & 7.23 & 2.72 \\
\hline 4 & 8.89 & 3.25 & 6.95 & 2.71 \\
\hline 5 & 8.81 & 3.11 & 6.88 & 2.64 \\
\hline 6 & 9.96 & 3.91 & 7.88 & 2.90 \\
\hline 7 & 9.35 & 3.70 & 6.84 & 2.92 \\
\hline 8 & 9.05 & 3.45 & 6.50 & 2.36 \\
\hline Average & 9.17 & 3.51 & 7.08 & 2.74 \\
\hline
\end{tabular}

\section{The nutritive value of the rations}

The digestion in vitro was used to evaluate the starch equivalent of the grass samples. The digestion coefficients in vitro of organic matter were converted into digestion coefficients in vivo by using our last calculated regression formula (van der Koelen and Dijkstra, 1971) $\mathrm{y}=0.850 \mathrm{x}+11.93$, in which $\mathrm{x}=$ the values in vitro and $\mathrm{y}=$ the digestion coefficients of organic matter in vivo. The starch equivalents in dry matter of the grass samples are calculated with the formula:

$\mathrm{SE}=\mathrm{dom}-0.06 \mathrm{dcp}-0.29 \mathrm{cf}$

in which dom $=$ digestible organic matter content; $\mathrm{dcp}=$ digestible crude protein content; and $\mathrm{cf}=$ crude fibre content, all in dry matter. The digestible crude protein content is calculated with the formula:

$$
\mathrm{dcp}=0.942 \mathrm{x}^{\prime}+0.041 \mathrm{~m}^{\prime}-4.09
$$

in which $\mathrm{x}^{\prime}=$ crude protein content in dry matter and $\mathrm{m}^{\prime}=$ ash content in dry matter.

In this way we found for starch equivalent figures fluctuating from 58.2 to 62.3 and for digestible crude protein between 21.2 to $26.1 \%$ in dry matter. The average starch equivalent was for the dry cows 60.6 and for the lactating cows 60.2 . For digestible crude protein content the average figures were 23.4 and 23.0 , respectively. From these figures we calculated the intake of nutritive value mentioned in Table 5.

The average daily intake of starch equivalent was for the lactating cows $9.17 \mathrm{~kg}$. They need - if we assume for maintenance of these lactating cows in pasture $3.0 \mathrm{~kg}-$ in total, on an average, $8.38 \mathrm{~kg}$ of starch equivalent per cow per day. Consequently the lactating cows were fed about $10 \%$ above the starch equivalent standards. If we assume that dry cows 1 to 2 months before calving need $5.86 \mathrm{~kg}$ starch equivalent (maintenance $+10 \mathrm{~kg}$ milk), the dry cows were fed about $20 \%$ above the standards. This was in our opinion in accordance with what happened; there was no decrease in milk production of all lactating cows and a very good condition of the dry cows. The amounts of digestible crude protein were 2.2 and 2.7 times too high, respectively, but this did not give any trouble in this trial. 


\section{References}

Chandler, P. T., E. M. Kesler \& R. D. McCarthy, 1964. Polyethylene as a reference substance for digestion studies with young ruminants. J. Dairy Sci. 47: 1426.

Dijkstra, N. D. \& A. Kemmink, 1970. De voederopname door grazende herkauwers. II. Beweidingsproeven met melkkoeien, waarbij verschillende exogene en endogene indicatoren worden vergeleken. Versl. landbouwk. Onderz. 738.

Kemmink, A. \& N. D. Dijkstra, 1968. De voederopname door grazende herkauwers. I. Chroomoxyde en polyethleen als exogene indicatoren en chromogeen als endogene indicator voor de bepaling van de grasopname. Versl. landbouwk. Onderz. 717.

Koelen, C. J. van der \& N. D. Dijkstra, 1971. De in-vitro verteerbaarheidsbepaling als hulpmiddel bij de schatting van de voederwaarde van ruwvoeders. In press. 